\title{
Hepatitis C Genotypes Distribution in Intravenous Drug Users in Tehran
}

\author{
Seyed Moayed Alavian ${ }^{1, *}$ \\ ${ }^{1}$ Baqiyatallah Research Center for Gastroenterology and Liver Diseases, Baqiyatallh University of Medical Sciences, Tehran, IR Iran \\ *Corresponding author: Seyed Moayed Alavian, Baqiyatallah Research Center for Gastroenterology and Liver Diseases, Baqiyatallh University of Medical Sciences, Tehran, IR Iran. Tel/ \\ Fax:+98-2188945186, E-mail: alavian@thc.ir
}

Received: December 24, 2013; Accepted: June 28, 2014

Keywords:Hepatitis C; Genotype; Distribution

\section{Dear Editor,}

I read with interest the published article by Ranjbar Kermani et al. (1). Genotyping of hepatitis C virus (HCV) is important, which provides information about strain variation and characteristics of virus during the treatment and the therapy response rate (2). In addition, it is of epidemiologic value because it sheds light on whether prevalent HCV strains are similar to that endemic ones in a certain region, such as those in the Middle East countries $(3,4)$. The study by Ranjbar Kermani et al. (1) in low sample size but the result in injecting drug users (IDUs) was interesting. This study indicates that the dominant HCV genotypes among patients were $3 \mathrm{a}$ and $1 \mathrm{a}$ (1). Most of studies in Iran showed that the dominant genotype was1, which is more common than the other genotypes $(2,4$, $5)$. It may be related to their study on IDUs group. Zahedi et al. reported similar data with dominancy of genotype 3 in patients with a history of heroin abuse (6). HosseiniMoghaddam et al. reported the genotype $3 \mathrm{a}$ as a more common genotype in patients underwent hemodialysis in Tehran (7).

In comparison with studies made in Yemen, Kuwait, Iraq, and Saudi Arabia, the most common genotype was type 4 (8). However, subtype $1 \mathrm{~b}$ in Turkey or the western border of Iran and subtype $3 a$ in Pakistan or eastern border of Iran are more prevalent (3). Genotyping was performed using type-specific primers (1) and they did not report any case with mixed genotype. It was related to the limitation of their method, in the other studies from Tehran, mixed HCV genotypes were also found in $2.5 \%$ of cases (2). Ranjbar Kermani et al. did not report any data about the relationship between age and distribution of HCV genotypes (1). Jahanbakhsh Sefidi et al. reported that subtype 1a was the most frequent genotype in pa- tients over 40 years of age and subtype 3a was the most frequent ones in patients younger than 40 years old (2). It seems that distribution pattern of HCV genotypes has changed during recent years and today the infection with genotype $3 a$ is increasing among IDUs and general population with HCV infection (9).

\section{References}

1. Ranjbar Kermani F, Sharifi Z, Ferdowsian F, Paz Z, Zamanian M. Distribution of Hepatitis C Virus Genotypes Among Chronic Infected Injecting Drug Users in Tehran, Iran. Jundishapur J Microbiol. 2013;6(3):265-8.

2. Jahanbakhsh Sefidi F, Keyvani H, Monavari SH, Alavian SM, Fakhim S, Bokharaei-Salim F. Distribution of hepatitis C virus genotypes in Iranian chronic infected patients. Hepat Mon. 2013;13(1).

3. Shah HA, Jafri W, Malik I, Prescott L, Simmonds P. Hepatitis C virus (HCV) genotypes and chronic liver disease in Pakistan. J Gastroenterol Hepatol.1997;12(11):758-61.

4. Ziyaeyan M, Alborzi A, Jamalidoust M, Badiee P, Moeini M, Kadivar A. Prevalence of hepatitis $C$ virus genotypes in chronic infected patients, southern Iran.JundishapurJ Microbiol. 2011;4(3):141-6.

5. Bokharaei-Salim F. Hepatitis C genotypes in hemophilia patients in iran. Iran Red Crescent Med J. 2011;13(2):146-7.

6. Zahedi MJ, Darvish Moghadam S, Hayatbakhsh M, Arabzadeh SA, Yazdani V. Prevalence of common types of hepatitis $C$ virus genotypes and the relation beyween age, sex and transmission risk factors in Kerman, Iran. Iran J Virol. 2007;1(2):15-9.

7. Hosseini-Moghaddam SM, Keyvani H, Kasiri H, Kazemeyni SM, Basiri A, Aghel N, et al. Distribution of hepatitis C virus genotypes among hemodialysis patients in Tehran--a multicenter study. $J$ Med Virol. 2006;78(5):569-73.

8. Kabir A, Alavian SM, Keyvani H. Distribution of hepatitis C virus genotypes in patients infected by different sources and its correlation with clinical and virological parameters: a preliminary study. Comp Hepatol. 2006;5:4.

9. Samimi-Rad K, Nasiri Toosi M, Masoudi-Nejad A, Najafi A, Rahimnia R, Asgari F, et al. Molecular epidemiology of hepatitis C virus among injection drug users in Iran: a slight change in prevalence of HCV genotypes over time. Arch Virol. 2012;157(10):1959-65. 